\title{
Павло Шидловський Микола Чорний
}

\section{НАУКОВЕ ОБҐРУНТУВАННЯ ДОЦІЛЬНОСТІ ПЕРЕДАЧІ ТЕРИТОРІЇ МЕЖИРІЦЬКОЇ СТОЯНКИ ШЕВЧЕНКІВСЬКОМУ НАЦІОНАЛЬНОМУ ЗАПОВІДНИКУ}

В статті подається техніко-економічне обґрунтування доцільності передачі території Межиріцької верхньопалеолітичної стоянки до складу Шевченківського національного заповідника. Аргументується, що така передача дозволить застосувати до цієї пам'ятки національного значення весь комплекс пам'яткоохоронних та реставраційних заходів, убезпечить пам'ятку від подальшої руйнації та стане початком дій по створенню музейного комплексу.

Ключові слова: пам'ятка археології національного значення, верхній палеоліт, музеєфікація, заповідник, пам'яткоохоронні дослідження.

\section{ВСТУП}

Палеолітичні пам'ятки зі збереженим культурним шаром та об'єктами - рідкісне явище для первісної археології, тим більше, якщо ми маємо справу зі стоянками зі збереженими рештками первісної архітектури з використанням кісток мамонта. Такі пам'ятки виявлені виключно на території Східної Європи, серед яких комплекси, що давно стали класичними з точки зору джерелознавства для вивчення та інтерпретації первісного господарства, соціальної структури та духовної культури мисливських суспільств. До таких унікальних об'єктів відноситься пам'ятка археології національного значення - Межиріцьке поселення мисливців на мамонтів, що має більш ніж 50-річну історію досліджень, результати яких відобразилися в узагальнюючих працях з первісної історії та археології України (Гладких 1990; Гладких, Станко 1997).

Межиріцька стоянка - унікальна пам'ятка первісної археології, яка датується в межах 17 13 тис. рр. від наших днів, безумовно, має загальносвітове значення з огляду на їі археологічну, антропологічну, культурознавчу цінність і яка $\epsilon$ вагомим джерелом для розкриття питань взаємозв'язку природи та суспільства в доісторичні часи. Яскравою особливістю Межиріцького поселення $\epsilon$ виявлення решток житлових конструкцій з використанням кісток мамонта та до- брим станом збереженості культурних шарів з фауністичними рештками, виробами з кістки, бивню мамонта та кременю. Від часу виявлення у 1965 р. археологічними дослідженнями території стоянки було виявлено рештки від чотирьох палеолітичних жител, та низки господарських ям, майстерень, ділянок культурних шарів, що їх оточували. Перші три житла, досліджених експедицією акад. І.Г. Підоплічка, були повністю розкопані та досліджені. Реконструкція житла №1 стала окрасою експозиції палеонтологічного відділу Національного науково-природничого музею НАНУ і здобула славу всесвітньо відомого артефакту, який репрезентує археологію України палеолітичної доби (Пидопличко 1969; 1976).

На площі стоянки розташовуються рештки четвертого житла з кісток мамонта, яке було відкрите та частково досліджене проф. Київського національного університету імені Тараса Шевченка М.І. Гладких. Ця конструкція $є$ яскравим свідченням найдавніших форм архітектури, використаних Homo sapience в суворих прильодовикових умовах із наявною утилітарною, ергономічною, естетичною та світоглядними функціями, що характеризує її саме як житло (Гладких, Корнієць 1979; Гладких 1999).

Починаючи від самого відкриття четвертого житлового комплексу постала проблема збереження пам'ятки як визначного археологічно-

Шидловський Павло Сергійович, к.і.н., доцент Київського національного університету імені Тараса Шевченка, вул. Володимирська, 64, Київ, 01601, Україна; асоційований дослідник у Muséum national d'Histoire naturelle, Département Homme et Environnement, Франція; ORCID:0000-0001-6771-812X, e-mail: prehist@knu.ua

Чорний Микола Гаврилович, к.б.н., провідний науковий співробітник Шевченківського національного заповідника, міжнародний експерт 3 питань створення та функціонування природно-заповідних територій, Канів, 19003, Україна, e-mail: mykola_kaniv@ukr.net 
го об'єкта. У 1977 році з метою музеєфікації 4-го межиріцького житла постановою Бюро Президії Академії наук УРСР вирішено створити на території пам'ятки науково-дослідну лабораторію-музей «Стійбище мисливців на мамонтів». 3 метою забезпечення умов археологічних досліджень та збереження культурних шарів, у 1980-х рр., за сприяння Академії наук УРСР було відселено мешканців садиб, на площі яких розташовувалась стоянка.

Однак $з$ тих часів ідею про створення музейного комплексу на території стоянки так і не було втілено у життя. Одна з основних причин цього відсутність документації на земельну ділянку та невизначеність іiі балансоутримувача. Відсутність установи, яка 6 була відповідальною за стан пам'ятки негативно позначилось на стані збереженості первісного житла - залишки споруди, які залишались тривалий час без охорони, неодноразово ставали об'єктом грабіжницьких дій, а металеве накриття, споруджене над пам'яткою, не забезпечувало схоронність об'єкта від впливу природних факторів. Збереження решток споруди з кісток мамонта в повній мірі залежало від дослідницьких груп Інституту археології НАН України, Київського національного університету імені Тараса Шевченка та ГО Центр палеоетнологічних досліджень, співробітниками яких проводились консерваційні та відновлювальні роботи над рештками житла.

В останні два десятиліття були пропозиції і велись підготовчі роботи щодо включення пам'ятки до складу Канівського біосферного заповідника (Чорний та ін. 2012; Чорний, Чорна 2013) та національного природного парку «Середньодніпровський» (Чорний 2021). Але нині ці проекти залишаються нереалізованими.

Такий стан справ став причиною звернення у 2018 р. керівника Межиріцької археологічної експедиції КНУ Павла Шидловського до керівництва Шевченківського національного заповідника 3 ініціативою взяття пам'ятки на баланс та включення цієї території в склад заповідника. Реалізація цього проекту передбачає розроблення відповідного техніко-економічного обґрунтування, яке наводиться нижче.

Техніко-економічне обґрунтування доцільності передачі Шевченківському національному заповіднику Міністерства культури та інформаційної політики України пам'ятки археології «Стоянка» (дата: 1,5 млн. - 10 тис. років до н.е., с. Межиріч, охоронний номер 230017-Н, Постанова КМУ від 03.09.2009, №928. - Межиріцьке поселення мисливців на мамонтів 14,5 15 тис. рр. до н.е.)

Техніко-економічне обґрунтування (далі ТЕО) розроблено відповідно до наказу Міністерства економічного розвитку і торгівлі України від 27.12.2013 №1591 «Про затвердження Методичних рекомендацій щодо розроблення технікоекономічного обґрунтування забезпечення ефективного використання об'єктів права державної та комунальної власності, що пропонуються».

1. Загальна характеристика майна, що передається

Адреса об'єкту: Черкаська обл., Черкаський р-н, с. Межиріч, вул. Канівська, 6. Орієнтовна площа земельної ділянки, пропонованої для передачі Шевченківському національному заповіднику, становить 1,54 га, складається із двох частин і розташована на території с. Межиріч Канівської ОТГ Черкаської області на відстані 18 км від Шевченківського національного заповідника. Картасхема ділянки, складена на основі публічної кадастрової карти України, додається (рис. 1: А). Перша частина, земельна ділянка площею 0,78 га, на якій безпосередньо знаходиться пам'ятка археології, призначена для проектування, реставрації, реконструкції об'єктів і Музею «Поселення мисливців на мамонтів». Ділянка знаходиться в північно-західній частині села Межиріч і межує із садибною житловою забудовою, автодорогою державного значення Канів-Черкаси-Чигирин. 3 південно-східної сторони межує з провулком Музейний. На ній знаходиться старий житловий будинок, що підлягає зносу в перспективі, льох, криниця із свердловиною, зелені насадження, а також металевий павільйон над рештками первісного житла (Житло 4).

Межиріцька стоянка мисливців на мамонтів $\epsilon$ пам'яткою археології національного значення (постанова Кабінету Міністрів України від 03.09.2009 р. №928, охоронний №230017-Н), яка вже понад півстоліття $є$ об'єктом дослідження і не втратила свою цінність в якості наукового джерела для розкриття питань взаємозв'язку природи і суспільства в доісторичні часи. 31966 р. на площі пам'ятки відкрито чотири житла первісних людей 3 використанням кісток мамонта у споруді. Три 3 них повністю розкопані. Четверте житло виявлене експедицією Київського державного університету імені Т.Г. Шевченка під керівництвом д.і.н., проф. М.І. Гладких у 1976 р. Рештки житла були розчищені ззовні, частково досліджені і залишені на місці з метою майбутньої музеєфікації та створення науково-дослідної лабораторії-музею (Постанова №162-Б Бюро Президії Академії наук УРСР, від 6 квітня 1977 р. “Про створення науководослідної лабораторії Інституту зоології АН УРСР «Стійбище мисливців на мамонтів»"). Відповідно до паспорту пам'ятки, виготовленого за радянського часу, рішенням виконкому Черкаської обласної ради №116 від 26 червня 1990 р. пам'ятка 
взята під охорону. Але межі охоронної зони не були встановлені. Поновлення паспорту не проводилось. На даний час пам'ятка не перебуває на балансі, не паспортизована, охоронний договір відсутній.

По іншу сторону автодороги Канів-ЧеркасиЧигирин розташована друга ділянка площею 0,76 га, яка передбачена Генеральним планом с. Межиріч 1983 р. під меморіальний комплекс «Межиріцька стоянка мисливців на мамонтів». Кадастровий номер відсутній. На земельній ділянці розташоване нерухоме майно - адмінбудівля колишньої контори колгоспу - яке, згідно договору купівлі-продажу приміщення адмінбудівлі, знаходиться у приватній власності. Ця земельна ділянка, згідно генплану села, знаходиться в перспективній зоні археологічних розкопок.

Окрім пам'ятки епохи палеоліту, на площі цих ділянок виявлено культурні шари епохи бронзи (бабинська культура), скіфського періоду та пізнього середньовіччя. Відповідно до висновку Департаменту культури та взаємозв'язку з громадськістю Черкаської ОДА на вказаній території забороняються будь-які земляні роботи, що передбачають переміщення ґрунту глибше 0,3 м від рівня сучасної денної поверхні, в т.ч. шляхові, будівельні та пов'язані із прокладанням інженерних мереж, благоустроєм території та встановленням огорож (окрім плям забудови вже існуючих будівель і споруд).

В генеральному плані враховані проектні рішення генерального плану меморіального комплексу «Межиріцька стоянка мисливців на мамонтів», розроблені ПП «Ларо».

Сучасний стан пам'ятки. Пізньопалеолітична стоянка Межиріч - пам'ятка археології національного значення (№230017-Н) - знаходиться на території с. Межиріч Канівської ОТГ Черкаської обл. Стоянка розташована на мисі, утвореному долинами річок Росі та Росави біля 12 км на захід від р. Дніпро, за 200 м від високого корінного схилу плато у долині р. Рось. Палеолітичні культурні рештки пам'ятки залягають на глибині 2,5 - 3 м від сучасної поверхні мису, в лесових відкладах другої надзаплавної тераси Росі. Більша частина радіовуглецевих дат визначають вік стоянки у досить вузьких межах - близько середини 15 тисячоліття від наших днів.

В результаті досліджень з 1966 по 1974 рр. експедиції під керівництвом акад. І.Г. Підоплічка на площі пам'ятки виявлено три житла з використанням кісток мамонта у споруді. 31976 по 1989 рр. розкопки стоянки та міждисциплінарні дослідження на ній проводилися експедицією під керівництвом завідувача кафедри археології, етнографії та музеєзнавства Київського державного університету ім. Т.Г. Шевченка, проф. М.І. Гладких, результатом чого стало відкриття четвертого житла з кісток мамонта та цілої низки ям і ділянок культурного шару (Гладких, Корниец 1977) (рис. 1: Б).

Залишки житла являють собою скупчення кісток мамонта у формі видовженого овалу розміром 5,85 м x 4,62 м, довга вісь якого орієнтована із заходу на схід. Висота над рівнем давньої поверхні становила 0,6 м, що добре простежується за характером розташування кісток поза межами споруди. Основним матеріалом конструкції споруди використано великі кістки мамонта, які складали функціонально різні в архітектурному відношенні частини: виділяється основа - «фундамент» - концентричне коло з черепів мамонта та інших великих кісток, зовнішня обкладка житла - лопатки, нижні щелепи, тазові, бивні тощо та перекриття житла, що впало всередину конструкції і складалось переважно з бивнів та пласких кісток (Рис. 2).

На сьогоднішній день, завдяки роботам Межиріцької експедиції кафедри археології та музеєзнавства Київського національного університету імені Тараса Шевченка, вдалось запобігти руйнації пам'ятки та проведено необхідні реставраційні роботи над кістковими рештками, що складають основу конструкції (Шидловський 2013). В останні роки (2018-2020), важливого значення для розуміння житлового простору первісного колективу стало дослідження конструктивних особливостей та внутрішнього заповнення четвертого житла (Shydlovskyi et al. 2019).

Питання збереження решток четвертого житла Межиріцької стоянки почало вирішуватись завдяки INQUA project 1804S: Mezhyrich International Archaeology Summer School, interdisciplinary study of an Upper Pleistocene site (2018) (Shydlovskyi et al. 2018) та проекту № Ф77/38811 Державного фонду фундаментальних досліджень «Межиріцька стоянка мисливців на мамонтів: археологічні дослідження та музеєфікація» (2017-2018) (http://vovkcenter.org.ua/en/2018-pn/ , Шидловський та ін. 2020).

В ході реалізації цих проектів було розчищено та реставровано великі кістки мамонта - частини конструкції первісної будівлі, та відбулось навчання групи аспірантів з навчальних закладів України та Франції неруйнівним методам дослідження та фіксації археологічних об'єктів під керівництвом спеціалістів з первісної археології, зооархеології та четвертинної геології.

Однак реставраційні роботи стосувались лише решток житла, в той час як для подальшого збереження пам'ятки археології $\epsilon$ необхідність повного накриття об'єкту разом з навколишніми ділянками культурного шару та проведення робіт з водовідведення. Рештки давньої споруди, які знахо- 
дяться у відкритому стані з часу їхнього відкриття у 1978 р., поступово піддаються руйнації від дії природних (повітря, волога) та людських (грабіжництво) факторів.

2. Обґрунтування доцільності здійснення передачі та відповідність функціонального призначення об'єкта передачі завданням, покладеним на орган, якому пропонується передати відповідний об'єкт

Територія межиріччя Росі та Росави на Черкащині $\epsilon$ окремим археологічним регіоном, в якому, з огляду на географічну специфіку, сконцентрована значна кількість пам'яток, які датуються від пізньопалеолітичного часу до доби раннього залізного віку (Шидловський та ін. 2018). Чільне місце серед об'єктів археологічної спадщини займає Межиріцька пізньопалеолітична стоянка, рештки якої демонструють найдавніші форми архітектури - житла з використанням кісток мамонта у споруді, що будувались мешканцями Східноєвропейської рівнини в часи останнього льодовикового періоду в 22-14 тис. рр. тому. На поточний момент четверте житло Межиріцької стоянки, разом 3 музеєфікованими об'єктами первісної архітектури в Добранічівці та Гінцях, унікальна пам'ятка, що залишена in situ з моменту свого відкриття зі збереженим культурним шаром і тому становить значну цінність з археологічної, антропологічної, культурознавчої точок зору.

3 огляду на те, що в даній пам'ятці поєднуються культурний шар, конструктивні та естетичні елементи споруди та факт тривалого вивчення пам'ятки відомими дослідниками первісності (акад. І.Г. Підоплічко, проф. М.І. Гладких, проф. О. Соффер, к. біол. н. Н.Л. Корнієць, к. істор. н. Д.Ю. Нужний), стоянка, як археологічний об'єкт, також $€$ пам'яткою архітектури, історії та монументального мистецтва.

Нині пам'ятка потребує:

- взяття на баланс;

- визначення меж;

- поновлення документації;

- комплексної охорони та організації наукових досліджень усіх наявних культурних шарів;

- паспортизації;

- оформлення охоронних зобов'язань;

- організації екскурсійного обслуговування.

Усі зазначені позиції входять, відповідно до діючого «Положення про Шевченківський національний заповідник», до переліку основних видів діяльності заповідника. Ці місця безпосередньо пов'язані із життям і творчістю Тараса Григоровича Шевченка. Тут він перебував у липні 1859 р., виконав малюнок «В Межирічі» і домовлявся з по- міщиком Никодимом Парчевським про купівлю ділянки землі біля с. Пекарі.

Логічним видається взяття відомої пам'ятки під опіку Шевченківського національного заповідника і з тої точки зору, що нині в структурі заповідника функціонує науково-дослідний відділ історико-краєзнавчих досліджень і окремий музей, присвячений історії Канівщини від давнини до сучасності, де в експозиції широко представлені археологічні і культурні артефакти цього регіону. Входження археологічної пам'ятки до складу Шевченківського національного заповідника дозволить застосувати весь комплекс пам'яткоохоронних заходів до об'єкту - реєстрація, дослідження, консервація, ревіталізація та музеєфікація.

3. Визначення джерел фінансування та обсягів витрат для подальшого утримання та використання зазначеного майна

У реалізації даного проекту враховувалась оцінка майбутніх туристичних і фінансових потоків. Залучення пам'ятки до екскурсійної діяльності заповідника дозволить збільшити кількість відвідувачів заповідника. Опитування, проведене серед відвідувачів заповідника, показує, що кожен третій екскурсант виявив бажання відвідати Межиріцьку стоянку мисливців на мамонтів. При середній вартості екскурсії 300 грн. для групи до 25 осіб і вартості вхідного квитка 50 грн., щорічні додаткові фінансові надходження складатимуть близько 1550000 грн. Після впорядкування об'єкту його можна включити до міжнародних туристичних маршрутів.

Унікальне місце розташування об'єкту, виключна естетична привабливість навколишніх ландшафтів, дозволить заповіднику надавати послуги, пов'язані зі створенням умов для організованого туризму, відпочинку (короткостроковий відпочинок, розбиття наметів і облаштування спеціальних місць для вогнищ. Орієнтовна вартість такої послуги складатиме 80 грн. з однієї особи. Необхідно обладнати приміщення для працівників, встановити пожежну та охоронну сигналізацію, впорядкувати територію та місця для відпочинку відвідувачів.

Для належного забезпечення роботи пам'ятки, як музейно-туристично-рекреаційного об'єкту, необхідно до штатного розпису заповідника додатково ввести такі посади завідувача відділу, касира, прибиральника, водія, екскурсоводів, сторожів (всього 8 штатних одиниць).

Фінансування діяльності об'єкту планується із наступних джерел:

- державний бюджет;

- кошти від екскурсійної та туристичної діяльності (як одна із складових держбюджету); 
- гранти;

- спонсорська допомога.

Початок залученню грантів на утримання об'єкту поклав у 2015 р. польсько-український проект «Створити село наново» за ініціативи представників місцевої громади. Основою проекту «Країна Мамонтляндія» стала археологічна пам'ятка - стоянка мисливців на мамонтів. Розважально-пізнавальна програма розрахована як на дітей, так і на дорослих. Тривалість - 4-4,5 год. Протягом 2014-2016 рр. учасників проекту навчали створювати тематичні села та популяризувати археологічну пам'ятку. У 2019 р. (до карантину) «Мамонтляндію» відвідало 3 тис. відвідувачів із усієї України. Це були діти і дорослі.

Завдяки співпраці Межиріцької археологічної експедиції Київського національного університету імені Тараса Шевченка з місцевою громадою та проектом «Країна Мамонтляндія», всередині металевого ангару з рештками житла було збудовано дерев'яну огорожу та настил для запобігання антропогенному впливу на конструктивні елементи споруди і захисту культурного шару від витоптування (Самойленко, Шидловський 2016) (Рис. 3).

В рамках проекту №Ф77/38811 Державного фонду фундаментальних досліджень «Межиріцька стоянка мисливців на мамонтів: археологічні дослідження та музеєфікація» (2017-2018) (виконавець - Київський національний університет імені Тараса Шевченка) з метою забезпечення технічних умов для проведення реставраційноархеологічних досліджень, екскурсійного відвідування пам'ятки та збереження експонатів здійснено впорядкування археологічного об'єкту. Окрім реставраційних та консерваційних робіт безпосередньо над рештками четвертого житла, було проведено електрифікацію ангару. Для запобігання розкраданням археологічних експонатів підведено сигналізацію за кошти спонсорів.

4. Прогноз ефективності діяльності суб'єкта після здійснення передачі майна (з визначенням етапів і термінів реалізації)

3 метою збереження пам'ятки та уникнення подальшої її руйнації, необхідно провести низку пам'яткоохоронних заходів, а саме:

- Юридичне та організаційне вирішення питання створення музею на території стоянки як підрозділу Шевченківського національного заповідника. Така передача дозволила 6 утримувати мінімальну адміністрацію на місці пам'ятки, забезпечила б практичну охорону, а також зробила 6 більш реальною перспективу побудови музейного комплексу. Разом з тим, важливим моментом $\epsilon$ визначення статусу території пам'ятки, поновлення пам'яткоохоронної документації на об'єкт, встановлення меж охоронної зони навколо нього
3 забороною будь-яких ландшафтних перетворень без наукової експертизи в межах території, що відведена для археологічного вивчення, згідно Генплану села Межиріч 1983 р.

- Пропонується музеєфікація решток четвертого житла з кісток мамонта Межиріцької стоянки, в якості центрального елементу Археопарку первісної культури. Досягнення цього можливе через проведення археологічних досліджень, реставраційних робіт, будівництва накриття над рештками об'єктів та лабораторних приміщень, облаштування території. На базі Межиріцької стоянки мисливців на мамонта в повній мірі може бути реалізований взаємозв'язок науки та суспільства: цей об'єкт може стати не тільки предметом вивчення науки про культурне і природне різноманіття, але і засобом комунікації, навчання, дозвілля, збагачення власного культурного досвіду. Археопарк, разом із музеєфікованим житлом палеолітичної доби, дозволять зберегти унікальні об'єкти для майбутніх поколінь та стануть основою для туристичної привабливості регіону та розвитку інфраструктури.

- Продовження археолого-реставраційних робіт над рештками житла. Така робота включає в себе реставрацію пошкоджених кісток мамонта, що становлять конструкцію житла (найбільших руйнувань кістки зазнали під час падіння металевого даху тимчасового накриття від значної кількості снігу у 2010 р.). Крім реставрації існує можливість відтворення втрачених, завдяки мародерству, частин споруди за фотографіями та планами первинного вигляду конструкції. Разом 3 тим, внутрішня частина житла частково замита від потрапляння води в конструкцію. Тому, для візуалізації первісного житла, необхідно продовжити археологічні розкопки всередині за ззовні споруди з залишенням виявлених матеріалів та конструктивних деталей на місці. Високий рівень проведених наукових досліджень підтверджується щорічно Відкритими листами НАН України та Дозволами Мінкультури на проведення досліджень пам'яток археологічної спадщини. Однак фінансування цих робіт залишається на досить низькому рівні.

- Побудова музейного комплексу та стаціонарної будівлі над спорудою. Остаточним вирішенням проблеми збереження житла доби палеоліту повинно стати спорудження стаціонарної музейної будівлі над рештками споруди, яка б мала необхідний режим температури та вологості та відповідала 6 нормам музейного будівництва. Така споруда дозволила б не тільки демонструвати пам'ятку відвідувачам, але й проводити всередині неруйнівні дослідження археологічних шарів та вмісту житла. Крім безпосередньо музейної 
споруди $\epsilon$ необхідність у побудові офісного приміщення для персоналу музею та працівників експедиції. Безумовно, що такі перетворення повинні супроводжуватись детальним археологічним вивченням тих площ, що підпадають під будівництво означених споруд.

\section{Необхідні види діяльності:}

1. Архівні дослідження.

2. Лабораторні роботи.

3. Проектні роботи та виготовлення пам'яткоохоронної документації, визначення територій археологічних пам'яток, встановлення зон охорони. Проектування будівель та території Археопарку.

4. Проведення археологічних досліджень на ділянках, що будуть порушені в ході будівельних робіт на території пам'ятки.

5. Будівництво приміщення музею зі збереженням житла №4 Межиріцької стоянки in situ (на першому поверсі), в якості основної пам'ятки, будівлі для лабораторних, камеральних робіт, туалету.

6. Проведення робіт з водовідведення, електрифікації, сигналізації тощо означених будівель.

7. Археологічні та реставраційні роботи в житлі №4 Межиріцької стоянки. Проводитимуться українськими спеціалістами галузі із залученням спеціалістів (археологів, зооархеологів, трасологів, геологів) з країн ЄС (Франції, Бельгії, Німеччини, Польщі). Археологічна школа для студентів, аспірантів та молодих учених з різних країн.

8. Роботи по відновленню первинного вигляду житла з використанням 3-Д друку елементів конструкції з кісток.

9. Створення експозиційної зали (другий поверх музейної будівлі). Створення культурного хабу на базі будівлі музею та території Археопарку для проведення відкритих лекцій, семінарів за тематикою розвитку людини та первісної культури. Проведення фестивалів первісного ремесла та експериментальної археології (кременеобробки, гончарства, тощо).

10. Впорядкування території пам'ятки (пандуси, лави, паркан).

11. Впорядкування територій навколишніх археологічних пам'яток (поселення трипільської культури, доби бронзи, скіфського часу, черняхівської культури, скіфського кургану), визначення охоронних зон та включення їхньої території до Археопарку, виготовлення охоронних дошок, вказівників.

Цільові групи (цільові групи - групи / організації, які безпосередньо отримуватимуть користь):

- місцева громада (залучення місцевих мешканців до роботи Археопарку, розвиток «зеленого туризму», розвиток місцевої інфраструктури);
- викладачі, студенти та аспіранти 3ВО (залучення студентів на волонтерських засадах до діяльності Археопарку, проведення навчально-виробничих студентських археологічних та музеєзнавчих практик на базі Археопарку);

- науковці, працівники музейних установ, краєзнавці (отримання наукової інформації щодо первісних пам'яток мікрорегіону, можливість апробації наукових концепцій під час натурного дослідження археологічних пам'яток);

- молодь і діти, що проживають в Канівській громаді (проведення екскурсій для дітей, залучення молоді до процесу створення та подальшого функціонування Археопарку, створення ширших можливостей для навчання у 3ВО, участі в «громадській науці»);

- вітчизняні та закордонні туристи (отримання доступної інформації про історію краю).

Кінцеві бенефіціари (отримає користь в довгостроковій перспективі на рівні суспільства або сектора в цілому).

1. Пам'яткоохоронний сектор. Впровадження результатів в пам'яткоохоронній галузі уможливлює збереження житла з кісток мамонта, створення постійної експозиції в музеї Археопарку, що дасть змогу в більшій мірі актуалізувати археологічну спадщину в сучасній Україні, унаочнить особливості культури первісних суспільств, дозволить експонування пам'ятки для відвідувачів, позитивно вплине на розвиток туристичної галузі та місцевої інфраструктури; Створення Археопарку передбачає розробку проектної документації, разом з паспортами та обліковими картками на пам'ятки археології місцевого та національного значення, постановку пам'яток на облік, що забезпечить збереженість об'єктів від будь-яких ландшафтних перетворень у майбутньому.

2. Туристичний сектор. На поточний момент туристичний потенціал регіону не $є$ розкритим у повній мірі. Археопарк та музей стануть унікальною атракцією, навколо якої відбудеться розвиток інфраструктури, закладів харчування, пунктів «зеленого туризму», що дозволить оживити депресивні села, залучити частину місцевих мешканців, особливо молоді, до діяльності Археопарку та викличе загальну зацікавленість серед мешканців громади до місцевої історії та розвитку людської культури загалом.

3. Освітній сектор - навчання під керівництвом висококваліфікованих професіоналів студентів, аспірантів та молодих учених Київського національного університету імені Тараса Шевченка, Національного університету Києво-Могилянська академія сучасним методикам дослідження архе- 
ологічних пам'яток, неруйнівним методам фіксації археологічних об'єктів та методам реставрації кісткових решток.

4. Науковий сектор - при проведенні археологічних та реставраційних досліджень будуть розчищені ділянки всередині та поза межами первісного житла, що дозволить з'ясувати структуру об'єкта, особливості матеріальної та поведінкової культури мешканців, характер адаптації мисливської групи до прильодовикових умов часу останнього зледеніння Європи; в результаті археологічних досліджень будуть отримані серії артефактів - вироби з кременю, кістки, бивня, що стануть джерелом наукового дослідження побуту та матеріальної культури первісного населення та дозволить застосувати низку наукових методів для розкриття аспектів життєдіяльності давнього суспільства, а саме: типолого-статистичного, технологічного, трасологічного, археозоологічного тощо. В ході подальшого функціонування Археопарку відбудуться дослідницькі дії, що передбачають польове дослідження, культурно-хронологічну атрибуцію, визначення меж археологічних пам'яток, що знаходяться в межиріччі Росі та Росави, а також рятівні розкопки на площі, яка буде відведена під музей та лабораторні приміщення. Археопарк стане базою для проведення міждисциплінарних досліджень в галузі археології, палеонтології, геології, палеоекології.

5. Органи місцевого самоврядування. Місцева громада с. Межиріч, мешканці Канівської ОТГ. Фінансова вигода для місцевої громади через залучення ширшого кола споживачів закладів харчування, пунктів зеленого туризму. Можливість отримання прибутку у перспективі через організацію платних екскурсій, надання публічного простору для проведення конференцій, семінарів, фестивалів ремісництва тощо.

Передбачається формування стійкої мережі взаємодії між музейною установою в Межирічі (Археопарку), як підрозділу Шевченківського національного заповідника, Канівською ОТГ, Трахтемирівським історико-культурним заповідником, археологічною експедицією Київського національного університету імені Тараса Шевченка, Центром палеоетнологічних досліджень, представниками «зеленого туризму», закладами харчування та при- ватними фірмами. Археопарк має стати фокусом привабливості для розвитку місцевої інфраструктури - доріг, закладів харчування, магазинів, інтернет-комунікацій, сувенірної індустрії. Приміщення Археопарку планується використовувати в якості освітньо-наукового хабу для проведення наукових конференцій, польових семінарів, екскурсій, краєзнавчих студій, мистецьких заходів, разом з активним залученням місцевих мешканців, особливо дітей, в якості цільової групи.

\section{ВИСНОВКИ}

В умовах сучасних приватизаційних процесів, бурхливого розвитку будівництва та інших форм антропогенного тиску на ландшафт, питання збереження пам'яток культурної спадщини, особливо національного значення, потребує втручання і взаємодії державних інституцій та громадськості. Особливо це стосується археологічних пам'яток, що належать до найдавніших етапів розвитку людини і суспільства. По-перше, тому, що ці археологічні об'єкти належать до загальної спадщини людства й несуть у собі інформацію про розвиток нашого біологічного виду та його культури), по друге, вони не відновлювані - при руйнації пам'ятки або ії частини інформація, яка могла 6 бути отримана з археологічного літопису, практично втрачається назавжди. Саме ці пам'ятки $\epsilon$ найбільш уразливими до антропогенного впливу: в переважній більшості вони зазнали значних перетворень і зрушень в результаті ландшафтних змін, пошкоджень наступними поколіннями мешканців, індустріальними та комунікаційними процесами.

Без подальших зусиль у напрямку музеєфікації Межиріцької стоянки зберегти комплекс $\epsilon$ проблематичним, адже експонування житлової конструкції з кісток мамонта у відкритому стані потребує цілого комплексу дій, що передбачає реставрацію кісткових решток на місці з паралельним археологічним дослідженням внутрішнього простору та прилеглої території житла. Застосування всього комплексу пам'яткоохоронних заходів та музеєфікацію Межиріцького комплексу можливо реалізувати через взяття Шевченківським національним заповідником цієї визначної археологічної пам'ятки під опіку. 


\section{ЛІТЕРАТУРА}

Гладких, М.І. 1991. Історична інтерпретачія пізнього палеоліту (за матеріалами території України): Препр. К.: НМК ВО. Гладких, М.И. 1999. Древнейшая архитектура по археологическим источникам эпохи палеолита. VITA ANTIQUA, № 1, c. 29-33. http://vitaantiqua.org.ua/wp-content/uploads/2016/11/004VA01-gladkikh.pdf

Гладких, М.И., Корниец, Н.Л. 1977. Исследование в Межириче. Археологические открытия 1976 года, с. $281-282$.

Гладких, М.І., Корнієць, Н.Л. 1979. Нова споруда з кісток мамонта в Межиріччі. Вісник АН УРСР, 9, с. 50-54.

Гладких, М.І., Станко, В.Н. 1997. Епоха пізнього палеоліту. В: Толочко, П.П. (ред.). Давня історія України. Т. 1. Первісне суспільство, р. II. К.: Наукова думка, с. 51-113.

Пидопличко, И.Г. 1969. Позднепалеолитические жилища из костей мамонта на Украине. К.: Наукова думка.

Пидопличко, И.Г. 1976. Межиричские жилища из костей мамонта. К.: Наукова думка.

Самойленко, Л.Г., Шидловський, П.С. 2016. Межиріцька стоянка: яке майбутнє в нашого минулого? Вісник Київського начіонального університету імені Тараса Шевченка. Історія, 4(131), с. 62-69. doi:10.5281/zenodo.1206223

Чорний, М.Г. 2021. Черкащина: вибір стратегії регіону. В: Чепура, Ф.М. (ред.). Стратегії сталого розвитку в туризмі та готельно-ресторанному бізнесі: можливості і проблеми запровадження в Україні: кол. монографія. Черкас. держ. технол. ун-т., Харків: СГ НТМ «Новий курс», с. 33-40.

Чорний, М.Г, Чорна, Л.О., Грищенко, В.М., Шевчик, В.Л. та ін. 2012. Заповідна Черкащина: історія, сьогодення, майбутнє: науково-довідкове видання (під заг. ред. М.Г. Чорного). Черкаси: Брама-Україна, 200 с.

Чорний, М.Г., Чорна, Л.О. 2013. Канівський природний заповідник: передумови створення, ретроспективний аналіз діяльності, сучасний стан та перспективи розвитку: монографія. К.: ВПЦ «Київський університет», 384 с.

Шидловський, П. 2013. Дослідження та проблеми збереження Межиріцького поселення мисливців на мамонтів. Праці НДІ пам'яткоохоронних досліджень, вип. 8, с. 567-581. doi:10.5281/zenodo.1188708

Шидловський, П., Пеан, С., Демей, Л., Крепін, Л., Цвіркун, О., Чимирис, М., Мамчур, Б. 2020. Поновлення досліджень четвертого Межиріцького житла. Археологічні дослідження в Україні, 2018, с. 244-247. doi:10.5281/zenodo.3751600

Шидловський, П., Синиця, Є., Тарахан-Береза, 3. 2018. Археологічне минуле Канівщини. В: Тарахан-Береза, 3. Святиня : Чернеча гора та стародавній монастир Канівський. Черкаси: IntroligaTOR, с. 7-16. doi:10.5281/zenodo.1432771

Shydlovskyi, P., Péan, S., Crepin, L., Tsvirkun, O. 2018. Investigating a Prehistoric mammoth bone dwelling: from field and lab research to education. Quaternary Perspectives, 25(2), p. 18-19. doi:10.5281/zenodo.2631382

Shydlovskyi, P.S., Tsvirkun, O.I., Péan, S., Chymyrys, M.V., Mamchur, B.V. 2019. New Study of Fourth Dwelling from Mezhyrich Upper Palaeolithic Campsite: the results of International Summer School activity. VITA ANTIQUA 11. Археологія, музеєзнавство, пам'яткознавство: освітній та дослідницький аспекти, с. 92-115. doi:10.37098/VA-2019-11-92-115

\section{REFERENCES}

Gladkikh, M.I. 1991. Istorychna interpretatsiia piznoho paleolitu (za materialamy terytorii Ukrainy): Prepr. Kyiv: NMK VO.

Gladkikh, M.I. 1999. Drevnejshaya arhitektura po arheologicheskim istochnikam epohi paleolita. VITA ANTIQUA, 1, s. $29-33$. http://vitaantiqua.org.ua/wp-content/uploads/2016/11/004VA01-gladkikh.pdf

Gladkikh, M.I., Kornietz, N.L. 1977. Issledovanie v Mezhiriche. Arheologicheskie otkrytiya 1976 goda, s. 281-282.

Gladkikh, M.I., Kornietz, N.L. 1979. Nova sporuda z kistok mamonta v Mezhyrichchi. Visnyk AN URSR, 9, s. 50-54.

Gladkikh, M.I., Stanko, V.N. 1997. Epokha piznoho paleolitu. In: Tolochko, P.P. (ed.). Davnia istoriia Ukrainy. T. 1.: Pervisne suspilstvo, r. II. Kyiv: Naukova dumka, s. 51-113.

Pidoplichko, I.G. 1969. Pozdnepaleoliticheskie zhilishcha iz kostej mamonta na Ukraine. Kyiv: Naukova dumka.

Pidoplichko, I.G. 1976. Mezhirichskie zhilishcha iz kostej mamonta. Kyiv: Naukova dumka.

Samoilenko, L.H., Shydlovskyi, P.S. 2016. Mezhyritska stoianka: yake maibutnie $v$ nashoho mynuloho? (Mezhyrich settlement:What will be the future of our past?). Bulletin of Taras Shevchenko National University of Kyiv, History, 4(131), s. 62-69. doi:10.5281/zenodo.1206223

Chornyi, M.H. 2021. Cherkashchyna: vybir stratehii rehionu. In: Chepura, F.M. (ed.). Stratehii staloho rozvytku v turyzmi ta hotelno-restorannomu biznesi: mozhlyvosti i problemy zaprovadzhennia v Ukraini: kol. monohrafiia. Cherkas. derzh. tekhnol. un-t., Kharkiv: SH NTM «Novyi kurs», s. 33-40.

Chornyi, M.H, Chorna, L.O., Hryshchenko, V.M., Shevchyk, V.L. et al. 2012. Chornyi, M.H. (ed.). Zapovidna Cherkashchyna: istoriia, sohodennia, maibutnie: naukovo-dovidkove vydannia. Cherkasy: Brama-Ukraina, $200 \mathrm{~s}$.

Chornyi, M.H., Chorna, L.O. 2013. Kanivskyi pryrodnyi zapovidnyk: peredumovy stvorennia, retrospektyvnyi analiz diialnosti, suchasnyi stan ta perspektyvy rozvytku: monohrafiia. Kyiv: VPTs «Kyivskyi universytet», $384 \mathrm{~s}$.

Shydlovskyi, P. 2013. Doslidzhennia ta problemy zberezhennia Mezhyritskoho poselennia myslyvtsiv na mamontiv. Pratsi NDI pamiatkookhoronnykh doslidzhen, vyp. 8, s. 567-581. doi:10.5281/zenodo.1188708

Shydlovskyi, P., Péan, S., Demay, L., Crepin, L., Tsvirkun, O., Chymyrys, M., Mamchur, B. 2020. Ponovlennia doslidzhen chetvertoho Mezhyritskoho zhytla. Arkheolohichni doslidzhennia v Ukraini, 2018, s. $244-247$.

doi: $10.5281 /$ zenodo.3751600 
Shydlovskyi, P., Synytsia, Ye., Tarakhan-Bereza, Z. 2018. Arkheolohichne mynule Kanivshchyny. In: TarakhanBereza, Z. Sviatynia: Chernecha hora ta starodavnii monastyr Kanivskyi. Cherkasy: IntroligaTOR, s. 7-16. doi:10.5281/zenodo.1432771

Shydlovskyi, P., Péan, S., Crepin, L., Tsvirkun, O. 2018. Investigating a Prehistoric mammoth bone dwelling: from field and lab research to education. Quaternary Perspectives, 25(2), p. 18-19. doi:10.5281/zenodo.2631382

Shydlovskyi, P.S., Tsvirkun, O.I., Péan, S., Chymyrys, M.V., Mamchur, B.V. 2019. New Study of Fourth Dwelling from Mezhyrich Upper Palaeolithic Campsite: the results of International Summer School activity. VITA ANTIQUA 11. Archaeology, Museum \& Monument Studies: educational and research aspects, s. 92-115. doi:10.37098/VA-2019-11-92-115

Shydlovskyi Pavlo S. ${ }^{1}$, Chornyi Mykola H. ${ }^{2}$

1 PhD, associate Professor at Taras Shevchenko National University of Kyiv, associate researcher in Human and Environment Department, National Museum of Natural History (France)

address: Volodymirska St, 64, Kyiv 01601, Ukraine

ORCID: $0000-0001-6771-812 \mathrm{X}$

e-mail: prehist@knu.ua

$2 \mathrm{PhD}$ in biological sciences, leading researcher at T. Shevchenko National Reserve, international expert on the creation and operation of nature reserves address: Kaniv 19003, Ukraine e-mail: mykola_kaniv@ukr.net

\section{SCIENTIFIC SUBSTANTIATION OF MEZHYRICH SETTLEMENT TRANSFER TO T. SHEVCHENKO NATIONAL RESERVE}

The Mezhyrich settlement is a unique vestige of prehistoric archaeology, dating back from 18 to 13 ka BP. This site is of worldwide importance due to its archaeological, anthropological, cultural value and which is an important source for revealing the issues of nature and society relationships in prehistoric times. A striking feature of the Mezhyrich settlement is the discovery of the remains of mammoth bone dwelling structures and a good state of preservation of cultural layers with faunal remains, bone, tusk and lithic artifacts. Since the discovery of the site in 1965, archaeological excavations have uncovered the remains of four Palaeolithic dwellings and a number of pits, workshops and plots of cultural layers around them. In the settlement are the remains of a fourth mammoth bone dwelling, which was discovered and partially explored by Prof. Mykhailo I. Gladkikh from the Taras Shevchenko National University of Kyiv.

In order to preserve the settlement and avoid its further destruction, it is necessary to carry out a number of site protection measures. Namely: 1 ) to take legal and organizational measures to address the issue of establishing a museum on the site as a subdivision of the T. Shevchenko National Reserve; 2) museification of the remains of the fourth mammoth bone dwelling, as a central element of the 'Archaeopark of prehistoric culture'; 3) continuation of archaeological and restoration works on the remains of dwelling. The final solution to the problem of preserving the remains of Palaeolithic housing should be the construction of a stationary museum building over the dwelling and surrounding cultural layers, which would have the necessary temperature and humidity and would meet the standards of museum building.

It will be problematic to preserve the Mezhyrich assemblage without further efforts in the direction of museification. After all, the exposure of a mammoth bone dwelling in the open state requires a whole set of actions, which involves the restoration of bone remains on site with a parallel archaeological study of the interior and the surrounding area. The T. Shevchenko National Reserve can realize the application of the whole complex of site protection measures and the museification of the Mezhyrich assemblage through the including of this outstanding archeological monument to its territory.

Keywords: archeological monument of national value, Upper Palaeolithic, museification, reserve, site protection studies. 

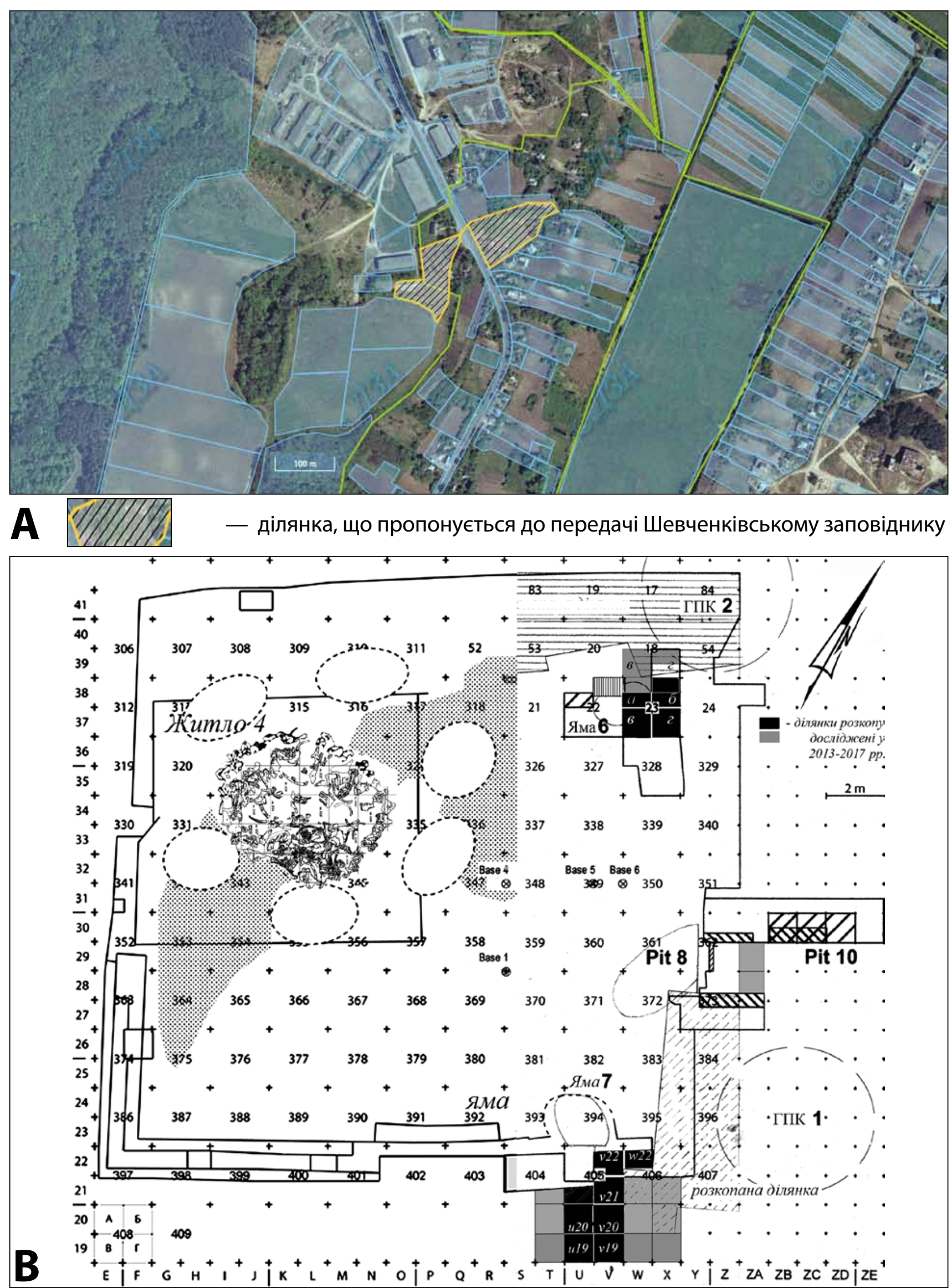

Рис. 1. Картографія Межиріцької стоянки: А - викопіювання кадастрової карти з позначенням меж території, що планується до передачі Шевченківському заповіднику; В - розкрита розкопками ділянка пам'ятки з рештками четвертого житла.

Fig. 1. Cartography of the Mezhyrich settlement: A - copy of the cadastral map indicating the boundaries of the territory planned for transfer to the T. Shevchenko Reserve; B - excavated area of the site with the remains of the fourth dwelling. 

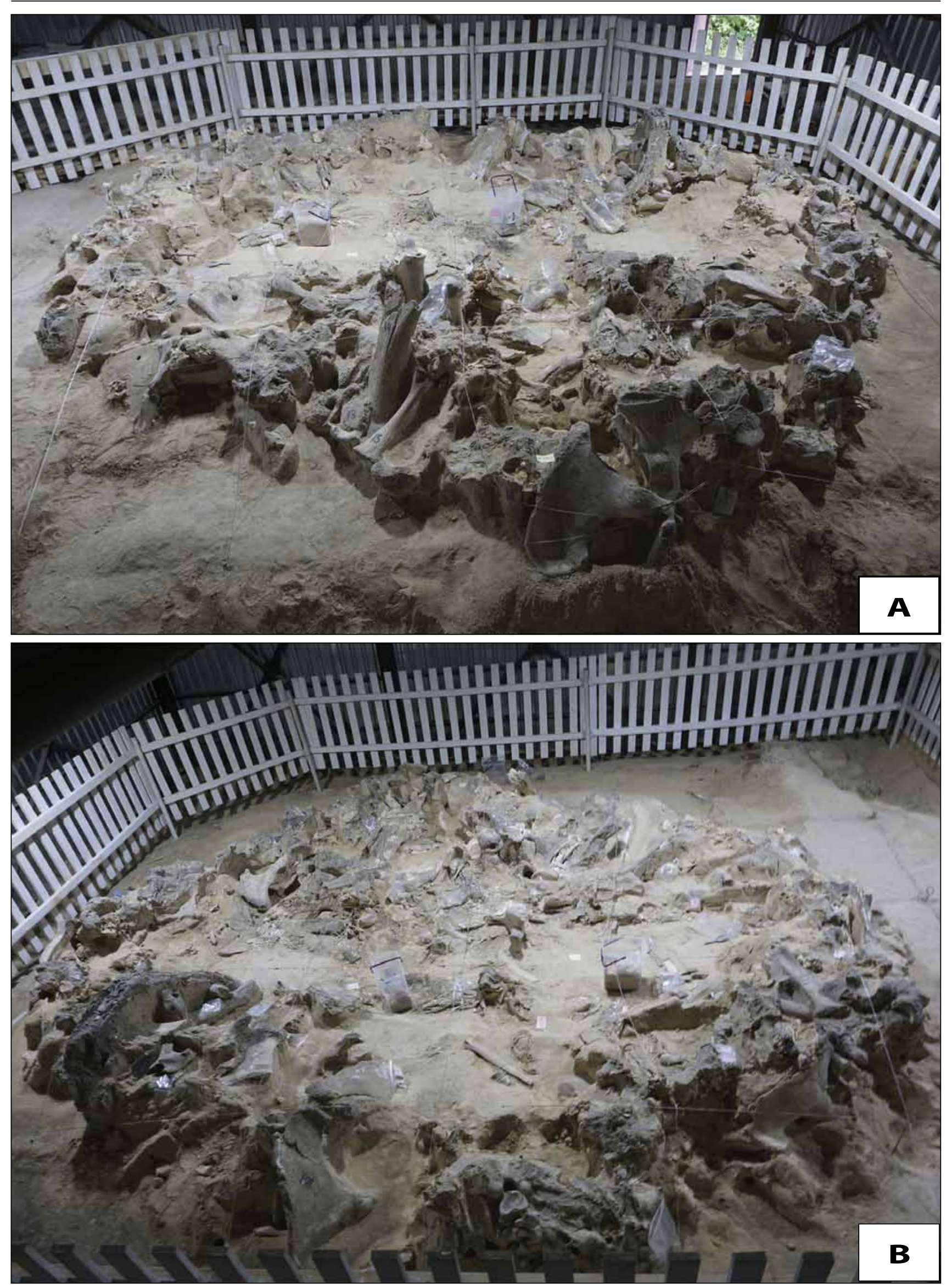

Рис 2. Сучасний стан решток четвертого житла Межиріцької стоянки: А - вигляд з південного сходу; В - вигляд 3 північного заходу (фото: С. Пеан, Ю. Черната).

Fig 2. The current state of the remains of the fourth Mezhyrich dwelling: A - view from the southeast; B - view from the northwest (photo: S. Péan, Yu. Chernata). 

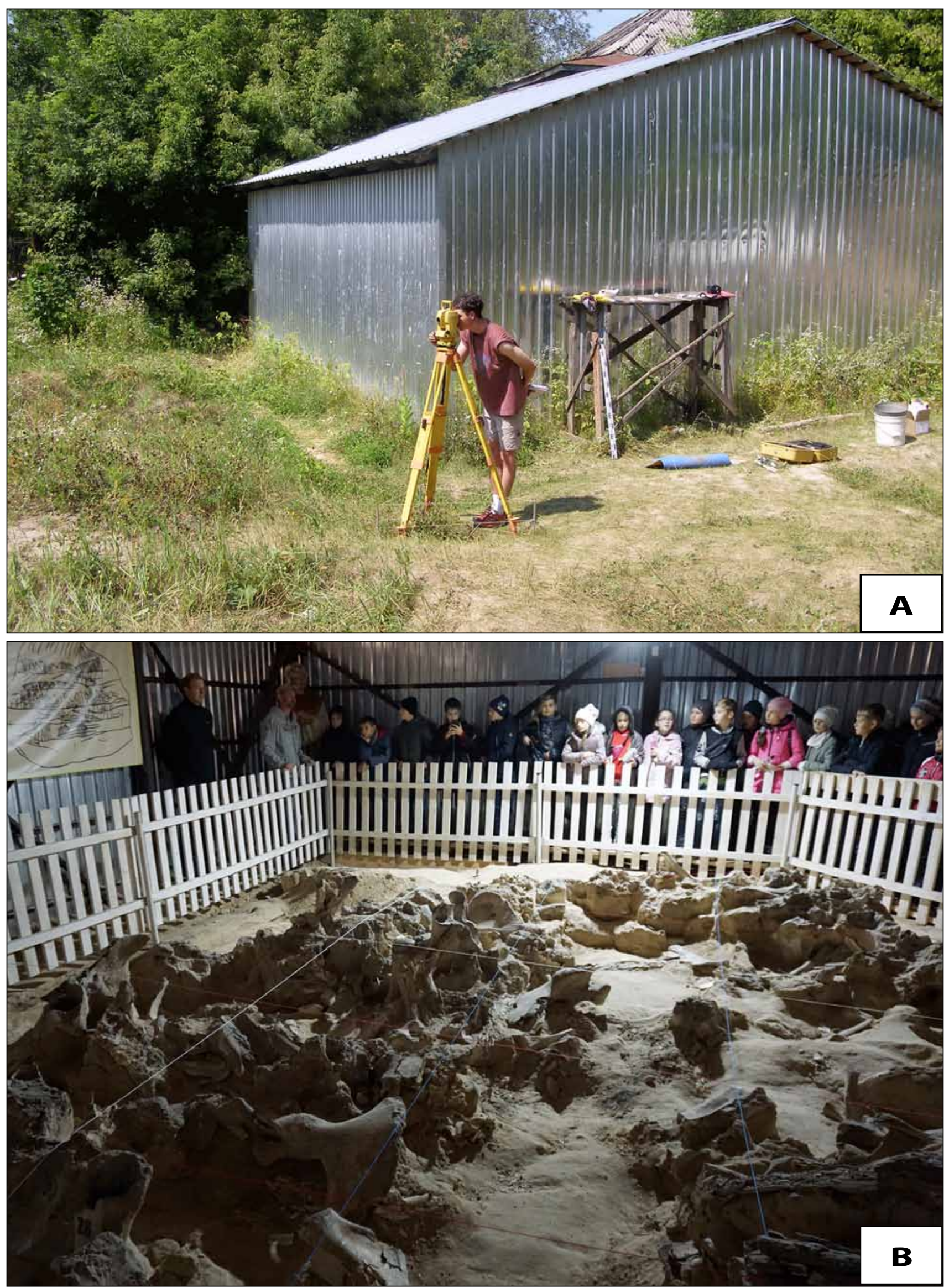

Рис 3. Дослідження та відвідування пам'ятки: А - металеве накриття над четвертим житлом; В - проведення екскурсії (фото: Ю. Черната, Н. Вукосавлєвіч).

Fig 3. Research and visiting the site: A - metal cover over the fourth dwelling remains; B - excursion (photo: Yu. Chernata, N.Vukosavljević). 